BIOKEMISTRI 17(1):27-32 (June 2005)

Available online at $h t t p: / / w w w . b i o l i n e . o r g . b r / b k$.

Abstracted online at www.ajol.info/journals/biokem

Printed in Nigeria
$\mathscr{A}_{n}$ international journal published by the

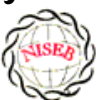

OVigerian Society for E̊xperimental \&iology

\title{
Increased liver alkaline phosphatase and aminotransferase activities following administration of ethanolic extract of Khaya senegalensis stem bark to rats
}

\author{
Musa T. YAKUBU*a, Oluwatope J. ADEBAYO ${ }^{\mathrm{b}}$, Evans C. EGWIM ${ }^{\mathrm{c}}$ and Victor B. OWOYELE \\ ${ }^{a}$ Department of Biochemistry, University of Ilorin, Ilorin, Nigeria. \\ ${ }^{b}$ Department of Physiology and Biochemistry, College of Medicine, University of Ilorin, Ilorin, Nigeria. \\ ${ }^{c}$ Science Laboratory Technology Department, Federal Polytechnic, Bida, Nigeria.
}

Received 20 February 2004

MS/No BKM/2005/003, @ 2005 Nigerian Society for Experimental Biology. All rights reserved.

\begin{abstract}
The effect of daily, oral administration of ethanolic extract of Khaya senegalensis stem bark $(2 \mathrm{mg} / \mathrm{kg}$ body weight) for 18 days on the alkaline phosphatase, aspartate and alanine aminotransferase activities of rat liver and serum were investigated. Compared with the control, the activities of liver alkaline phosphatase (ALP), alanine aminotransferase (ALT) and aspartate aminotransferase (AST) increased significantly for the 6 and 18 days period of extract administration $(\mathrm{P}<0.05)$ without corresponding significant increase in the serum enzymes $(\mathrm{P}>0.05)$. The results indicate that the ethanolic extract of Khaya senegalensis stem bark has brought about induction of synthesis of the liver enzymes studied which is an important biochemical symptom of cytolysis.
\end{abstract}

Key words: Khaya senegalensis, Stem bark, Ethanolic extract, Alkaline phosphatase, Aspartate aminotransferase, Alanine aminotransferase

*Author to whom all correspondence should be addressed.

E-mail: tomuyak@yahoo.com, Tel: +234-803-3578658 


\section{INTRODUCTION}

Many indigenous plants have been in the use of man since time immemorial for curing various ailments without the actual knowledge of their toxic potential(s). In Nigeria, one of such plants used by many localities is Khaya senegalensis.

Khaya senegalensis (Desr.) A. Juss. [familyMeliaceae] otherwise known as dry zone mahogany (English), aganwo (Yoruba) and madaci (Hausa), is a medicinal plant widely distributed in the Savannah region and commonly used by the Nupes of Niger State, Nigeria. The decoction of the stem bark is given as a remedy for malaria ${ }^{1}$. The stem bark contains scopoletin, scoparone, limonoid, bitter principle, tannins, saponins and sterols ${ }^{2}$. The stem bark and leaves have been reported to be effective against Plasmodium falciparum in vitro ${ }^{3}$. The stem and root bark have also been reported to have antisickling, antimicrobial and anthelmintic properties $^{1,4}$.

The growing interest in herbal medicine demands information on the toxicity risk assessment on the various plant preparations used in the management of diseases. It is in the light of this that the present study was set out to provide information on the safety/toxicity risk potential of Khaya senegalensis stem bark on the liver of albino rats. This was done by assaying for the activities of alkaline phosphatase and transaminases which are useful indicators of liver cytolysis and damage to hepatocyte's plasma membrane ${ }^{5,6}$.

\section{MATERIALS AND METHODS}

Twenty white albino rats of an inbred Novergicus strain (Rattus novergicus) weighing between $240 \mathrm{~g}-260 \mathrm{~g}$ were obtained from the Animal Holding Unit of the Department of Biochemistry, University of Ilorin, Ilorin, Nigeria. The alkaline phosphatase assay kit was procured from Quinica Clinica Aplicada, S.A., Spain while the aminotransferase assay kits were supplied by Randox Laboratories Ltd., United Kingdom. Other reagents used were of analytical grade and were prepared in all glassdistilled water.

\section{Plant Authentication and Extract Preparation}

The plant was authenticated at the Biology Unit, Federal Polytechnic, Bida, Niger State, Nigeria where voucher specimen has been deposited. Samples of Khaya senegalensis stem bark cut from trees located within Bida town of Niger State, Nigeria were collected in May, 2002. The stem bark was thereafter shade-dried at room temperature and grind into powder using electric blender/mill grater III (model MS-223, Taiwan). Two hundred grams portion of the sample was steeped in $500 \mathrm{ml}$ of absolute ethanol for two weeks after which it was filtered and evaporated at room temperature according to the method described by ${ }^{7}$. An aqueous preparation of the extract corresponding to the reported malaria parasite clearance curative dose of $2 \mathrm{mg} / \mathrm{kg}$ body weight ${ }^{3}$, was then made in distilled water before oral administration to the rats

\section{Animal Grouping/Treatment}

The rats were kept in well-ventilated house conditions (temperature: $28-31^{\circ} \mathrm{C}$; photoperiod: $12 \mathrm{~h}$ natural light and $12 \mathrm{hr}$ dark; humidity: $50-55 \%$ ) with free access to normal rat chow (Bendel Feeds and Flour Mills, Ltd., Ewu, Nigeria) and tap water. They were housed in plastic cages of dimension $165 \mathrm{~cm} \times 102.5 \mathrm{~cm} \times$ $95 \mathrm{~cm}$ with cleaning done twice daily. They were distributed into four groups of five rats each. Rats in group A were administered orally with $1 \mathrm{ml}$ of distilled water on daily basis for six days. This served as the control for six day administration. Those in group B were similarly treated like those in group A except that the administration of distilled water was done daily for 18days. This served as the control for 18 days administration. Groups $\mathrm{C}$ and $\mathrm{D}$ received $1 \mathrm{ml}$ of the extract on daily basis for 6 and 18days respectively. The administration of the extract was done at the reported curative dose of $2 \mathrm{mg} / \mathrm{kg}$ body weight.

The extract treated and the controls were studied in parallel with administration done by gastric intubation between $0800 \mathrm{hr}-0900 \mathrm{hr}$ daily. They were allowed free access to rat feed and water after the administration. Five rats in groups $\mathrm{A}$ and $\mathrm{C}$ were sacrificed 24hours after their 6 daily doses of the distilled water and the 
extract while equal number of rats from groups B and D were sacrificed 24hours after their 18th daily doses.

\section{Tissue sample collection and preparation}

Rats were anaesthetized in slight chloroform and blood samples collected into clean, dry centrifuge tubes by cardiac puncture. Blood samples which were processed individually were allowed to stand for 10mins at room temperature and then centrifuged at $1000 \mathrm{rpm}$ for $15 \mathrm{mins}$ on laboratory centrifuge (SM 800B, Surgifriend Medicals, England) and the supernatant (serum) carefully removed with Pasteur pipette, and stored frozen. The liver was then excised, cleansed of superficial connective tissues and then transferred into ice-cold $0.25 \mathrm{M}$ sucrose solution. It was later blotted with clean tissue paper and weighed. The tissue was cut finely with clean sterile blade before being homogenized in ice-cold $0.25 \mathrm{M}$ sucrose solution [1:5w/v] using Teflon homogenizer. The homogenates were kept frozen overnight to ensure maximum release of the enzymes ${ }^{8}$.

\section{Enzyme assays}

Alkaline phosphatase (EC 3.1.3.1) activity was assayed using the method described by Babson et al ${ }^{9}$. The procedure as described by Reitman and Frankel ${ }^{10}$ was employed for the assay of aspartate aminotransferase (AST) (EC 2.6.1.1) and alanine aminotransferase (ALT) (EC 2.6.1.2). Protein content was determined using Biuret reagent as described by Plummer ${ }^{11}$. All measurements were done using Spectronic 21 digital spectrophotometer (Bausch and Lomb, N.Y.).

\section{Statistical Analysis}

Data were presented as mean of 5 replicates \pm standard error of mean (SEM). Multiple comparisons of the mean values were carried out using One-Way Analysis of Variance (ANOVA) and complemented with the Student's t-test. The level of statistical significance was taken at 5\% confidence level.

\section{RESULTS}

The effects of administration of ethanolic extract of Khaya senegalensis stem bark to rats on the activities of alkaline phosphatase, aspartate aminotransferase (AST) and alanine aminotransferase (ALT) respectively are shown in Tables 1-3. The administration of the extract for 6 and 18days produced significant increase in the liver ALP activity as compared to the control $(\mathrm{P}<0.05)$. In contrast, no significant change was observed in serum alkaline phosphatase activity $(\mathrm{P}>0.05)$ Extract administration for 6 and 18days produced significant increase in the liver AST activity with that of 6days administration producing about $1 \frac{1 / 2}{2}$ fold increase while that of 18days administration produced $2 \frac{1}{2}$ fold increase over the control $(\mathrm{P}<0.05) \quad$ (Table 2). The administration of the extract for 6 and 18days did not produce any significant change in the serum AST activity ( $\mathrm{P}>0.05)$ (Table 2). Extract administration for six days resulted in significant reduction in the liver ALT activity with a corresponding significant increase in the activity of the serum enzyme $(\mathrm{P}<0.05)$ (Table 3$)$. Same administration for 18days however produced significant increase in liver ALT activity of about $60 \%$ the control $(\mathrm{P}<0.05)$ (Table 3), a pattern which did not reflect any significant change in the serum enzyme ( $\mathrm{P}>0.05)$ (Table 3$)$.

\section{DISCUSSION}

The measurement of the activities of marker or diagnostic enzymes in tissues plays a significant and well-known role in diagnosis, disease investigation and in the assessment of drug or plant extract for safety/toxicity risk. The enzymes considered in this study are useful marker enzymes of liver cytolysis and damage to the plasma membrane of the liver cells ${ }^{5,12}$.

Alkaline phosphatase is a marker enzyme for the plasma membrane and endoplasmic reticulum $^{13}$ of the tissue studied. It is often employed to assess the integrity of plasma membrane $e^{14}$, since it is localised predominantly in the microvilli of the bile canaliculi, located in the plasma membrane. The significant increase in the liver ALP activity (Table 1) following the administration of the plant extract may be due to increased functional activity of the liver ${ }^{15}$, probably leading to de novo synthesis of the enzyme molecules. Since alkaline phosphatase hydrolyses phosphate monoesters, the enzyme's hyperproduction could constitute a threat to the life of the cells that are dependent on a variety of 
Table 1: Effect of ethanolic extract of Khaya senegalensis stem bark ( $2.0 \mathrm{mg} / \mathrm{kg}$ body weight) on rat liver ALP

*Enzyme activity (U/I/mg protein)

Treatment

Day 6

Day 18

Liver

Serum Liver Serum

Control (Distilled water)

$45.21 \pm 5.34 \quad 18.02 \pm 3.00$

$46.50 \pm 7.01 \quad 18.50 \pm 2.80$

Extract

$64.50 \pm 3.24 * 20.00 \pm 2.20$

$71.50 \pm 5.22 * \quad 19.40 \pm 1.58$

*Enzyme activity is expressed as specific enzyme activity, $n=5 ; * P<0.05$

Table 2: Effect of ethanolic extract of Khaya senegalensis stem bark $(2.0 \mathrm{mg} / \mathrm{kg}$ body weight) on rat liver AST

*Enzyme activity (U/I/mg protein)

Treatment

Day 6

Liver

Serum Liver Serum

Day 18

Control

$122.00 \pm 14.22 \quad 77.21 \pm 6.80$

$132.00 \pm 10.10$

$78.00 \pm 8.50$

(Distilled water)

Extract

$190.00 \pm 39.21 * \quad 76.50 \pm 5.40$

$340.00 \pm 30.24 *$

$77.00 \pm 7.00$

*Enzyme activity is expressed as specific enzyme activity, $n=5 ; * P<0.05$

Table 3: Effect of ethanolic extract of Khaya senegalensis stem bark $(2.0 \mathrm{mg} / \mathrm{kg}$ body weight) on rat liver ALT

*Enzyme activity (U/I/mg protein)

\begin{tabular}{lclll} 
Treatment & \multicolumn{2}{c}{ Day 6 } & \multicolumn{2}{c}{ Day 18 } \\
& Liver & Serum & Liver & Serum \\
\hline Control (Distilled water) & $56.00 \pm 4.21$ & $30.40 \pm 3.80$ & $57.00 \pm 3.52$ & $31.00 \pm 3.40$ \\
Extract & $36.00 \pm 2.44^{*}$ & $52.50 \pm 4.63^{*}$ & $95.00 \pm 4.60 *$ & $32.50 \pm 3.50$ \\
\hline
\end{tabular}

*Enzyme activity is expressed as specific enzyme activity, $n=5 ; * P<0.05$ 
phosphate esters for their vital process ${ }^{16}$, as it may lead to indiscriminate hydrolysis of phosphate ester metabolite of the liver, an important biochemical symptom of cytolysis. Consequently, this may adversely affect the facilitation of the transfer of metabolites across the cell membrane. Such hyperproduction of liver ALP may suggest that the integrity of the liver plasma membrane was not compromised following the administration of the plant extract since there was no concomitant increase in serum ALP (Table 1).

Aspartate and alanine aminotransferases are normally localised within the cells of the liver, heart, gill, kidney, muscles and other organs. The enzymes are of major importance in assessing and monitoring liver cytolysis ${ }^{17}$. Their presence in the serum may give information on organ dysfunction ${ }^{18}$. The general increase in the activity of liver AST (Table 2) following extract administration for 6 and 18days could be due to de novo synthesis of the enzyme molecules or an adaptation by the liver to the assault from the plant extract leading to activity higher than the control $^{6}$.

The reduction in the liver ALT activity following administration of the extract for six days may be attributed to reduced rate of synthesis of the liver enzyme. It may also be that the extract has caused leakage of the enzyme into the blood via altered membrane permeability ${ }^{19}$. Cellular damage arising from plant extract administration can result in leakage of the marker enzymes to the extracellular fluid. Although, there was also a corresponding significant increase in the serum enzyme activity, it is not enough to infer leakage of the enzyme since the pattern of alkaline phosphatase activity (Table 1) did not indicate labilization of the plasma membrane. The increased serum ALT activity on day 6 (Table 3) may be attributed to contribution from other organs of the body. However, the elevated liver ALT activity observed on day 18 of extract administration may suggest an attempt at recovery from the assault inflicted on it by the first six days of administration leading to enzyme activities higher than the control. The attempt may be to counteract the reduced catalytic activity, as observed on day six, resulting in increased synthesis of the enzyme molecule (Table 3). The pattern of ALT and AST activities observed in this study are biochemical symptoms of liver cytolysis. The aminotransferases occupy a central position in the amino acid metabolism as they help in retaining amino groups (to form a new amino acid) during the degradation of amino acid and are also involved in the biochemical regulation of intracellular amino acid pool. They also help in providing necessary intermediates for gluconeogenesis. Alterations in their activities may have adverse effect on the amino acid metabolism of the tissues and consequently the intermediates needed for gluconeogenesis.

Results from this study has shown that daily, oral administration of the ethanolic extract of Khaya senegalensis stem bark for 18days at the reported malaria parasite clearance curative dose of $2.0 \mathrm{mg} / \mathrm{kg}$ body weight has induced the synthesis of the liver enzymes investigated. The pattern displayed by the enzymes in the study could be attributed to liver cytolysis.

\section{REFERENCES}

1. Gill, L. S. (1992) Ethnomedical uses of plants in Nigeria. University of Benin Press, Nigeria. Pp.143.

2. Gbile, Z. O. (1986) Ethnobotany, taxonomy and conservation of medicinal plants. In The state of medicinal plants research in Nigeria (eds Sofowora A). University of

Ibadan Press, Nigeria. Pp. 13-29.

3. Egwim, E. C., Badru, A. A. and Ajiboye, K. O. (2002) Testing pawpaw (Carica papaya) leaves and African Mahogany (Khaya senegalensis) bark for antimalaria activities. NISEB J 2(1): 37-39.

4. Full, A. B., Vanhaelen-Faster, R., Vanhaelen, M., Lo, I., Toppet, M., Ferster, A. and Fondu, P. (1999) In vitro antisickling activity of a rearranged Limonoid isolated from Khaya senegalensis. Plant Med 65(3): 209-212.

5. Schmidt, E and Schmidt, F. W. (1979) Enzyme diagnosis in diseases of the liver and biliary system. Adv. Clin. Enzymol. 1: 239-242. 
6. Yakubu, M T., Akanji, M. A. and Salau, I. O. (2001) Protective effect of ascorbic acid on some selected tissues of ranitidine-treated rats. Nig. J. Biochem. Mol. Biol. 16(2): 177-182.

7. Majekodunmi, O. F., Zany, I., Ohanyaga, I. E., Shi, L. E. and Malanghin, J. L. (1996) Selective cytotoxic diterpene from Euphorbia poisonic. J. Med. Chem. 39: 1005-1008.

8. Ngaha, E. O., Akanji, M.A and Madusolumuo, M. A. (1989) Studies on the correlation between chloroquine-induced tissue damage and serum enzyme changes in the rats. Experientia 45: 143-146.

9. Babson, A. L., Greeley, S. J., Coleman, C. $M$ and Philips, G. D (1966) Phenolphthalein mono-phosphate as a substrate for serum alkaline phosphatase. Clin Chem 12: 482-490.

10. Reitman, S and Frankel, S (1957) A colourimetric method for the determination of serum glutamate-oxaloacetate and pyruvate transaminases. Am J Clin Path 28: 56.

11. Plummer, D. T (1978) An introduction to practical Biochemistry (2nd ed.). McGraw- Hill, London. Pp. 144-145.

12. Shahjahan, M., Sabitha, K. E., Jainu, M. and Shyamala-Devi, C. S. (2004) Effect of Solanum trilobatum against carbon tetrachloride-induced hepatic damage in albino rats. Indian J. Med. Res. 120: 194-198.
13. Wright, P. J and Plummer, D. T (1974) The use of urinary enzyme measurement to detect renal damages caused by nephrotoxic compounds. Biochem. Pharmacol. 12: 65.

14. Akanji, M. A., Olagoke, O. A and Oloyede, O. B (1993) Effect of chronic consumption of metabisulphite on the integrity of the kidney cellular system. Toxicol 81: 173179.

15. Brain, R. T and Kay, H. D (1927) Kidney phosphatase. II: The enzyme in disease. Biochem J. 21: 1104-1108.

16. Butterworth, P. J and Moss, D. W. (1966) The effect of urea on human kidney alkaline phosphatase. Biochem. J. 99: 9-10.

17. Wada, H and Snell, E. E. (1962) Enzymatic transamination of pyridoxamine-pyruvate transaminase. J. Biol. Chem. 237: 133-137.

18. Wells, R. M., Mclntyre, R. H., Morgan, A. K and Davies, P. S. (1986) Physiological stress responses in big game fish after exposure: observation on plasma chemistry and blood factors. Comp. Biochem. Physiol. 64A: 565-571.

19. Wroblewski, F and La Due, J. S (1956) Serum glutamate pyruvate transaminase in cardiac and hepatic disease. Proc Soc Exp Biol Med 91: 569-571. 